\title{
UPAYA MENINGKATKAN HASIL BELAJAR SISWA DENGAN PENERAPAN METODE NUMBERED HEADS TOGETHER DALAM PEMBELAJARAN PKN
}

\author{
Enok Aminah \\ SD Negeri Karayunan II Majalengka, Indonesia \\ Enokaminah48@gmail.com
}

\begin{abstract}
Civics are subjects learned from elementary school to college. This Civics is important because it can provide moral lessons with a mission to educate the nation's life. However, civics learning conducted now does not fully give students an understanding of morals. This can be seen from the still low student learning outcomes in Civics subjects so that preventive measures are needed in overcoming the se problems. One way that can be sought is to use an appropriate learning model. The author tries to research the Numbered Heads Together learning model which is thought to be the right learning model in improving student learning outcomes in Civics subjects. This study aims to determine the effectiveness of the application of the Model Numbered Heads Together in improving student learning outcomes in Civics learning. This research was conducted at Class III Students in Class III SD Negeri Karayunan II Kec.Cigasong Kab. Majalengka Academic Year 2019/2020. The instruments used in this study were observation guidelines, interview guidelines, field notes, process evaluation sheets, and photo recordings. Data obtained, analyzed, and reflected using qualitative description methods. Conclusions can be drawn in the application of the Model Numbered Heads Together learning effectively creating a learning atmosphere that can enhance student interest in learning while creating a pleasant and meaningful learning atmosphere for students. Conditions have a major impact on improving student learning outcomes. Thus it can be concluded that the Model Numbered Heads Together can improve the process and student learning outcomes in Civics Learning..
\end{abstract}

Keywords: Discovery Model, Social Studies Learning, Learning Outcomes.

\section{ABSTRAK}

PKn adalah mata pelajaran yang dipelajari dari sekolah dasar hingga perguruan tinggi. PKn ini penting diberikan karena dapat memberikan pelajaran mengenai moral dengan misi untuk mencerdaskan kehidupan bangsa. Namun pembelajaran PKn yang dilaksanakan sekarang tidak sepenuhnya memberikan siswa paham mengenai moral. Hal ini dapat dilihat dari masih rendahnya hasil belajar siswa pada mata pelajaran PKn sehingga diperlukan langkah-langkah preventif dalam mengatasi permasalahan tersebut. Salah satu cara yang dapat diupayakan adalah menggunakan model pembelajaran yang tepat. Penulis mencoba melakukan penelitian model pembelajaran Numbered Heads Together yang diduga model pembelajaran yang tepat dalam meningkatkan hasil belajar siswa dalam mata pelajaran PKn. Penelitian ini bertujuan guna mengetahui efektivitas dari penerapan Model Numbered Heads Together dalam meningkatkan hasil belajar siswa pada pembelajaran PKn. Penelitian ini dilakukan pada Siswa Kelas III di Kelas III SD Negeri Karayunan II Kec.Cigasong Kab. Majalengka Tahun Pelajaran 2019/2020. Instrumen yang digunakan dalam penelitian ini adalah pedoman observasi, pedoman wawancara, catatan lapangan, lembar penilaian proses, dan rekaman poto. Data diperoleh, dianalisis, dan direfleksi dengan menggunakan metode deskripsi kualitatif. Dapat ditarik kesimpulan dalam penerapan pembelajaran Model Numbered Heads Together efektif menciptakan suasana belajar yang dapat meningkatkan minat belajar siswa sekaligus menciptakan suasana belajar menyenangkan dan bermakna bagi siswa. Kondisi berdampak besar pada peningkatan hasil belajar siswa. Dengan demikian dapat disimpulkan Model Numbered Heads Together dapat meningkatkan proses serta hasil belajar siswa dalam pembelajaran PKn.

Kata Kunci: Model Numbered heads together, Pembelajaran PKn, Hasil belajar.

Submitted December 1, 2019 | Revised December 15, 2019 | Accepted December 17, 2019

\section{Pendahuluan}

Pendidikan Kewarganegaraan (PKn) merupakan salah satu mata pelajaran wajib dalam kurikulum di semua jenjang pendidikan, mulai dari tingkat Sekolah Dasar (SD) sampai tingkat 
perguruan tinggi. Pendidikan Kewarganegaraan adalah mata pelajaran yang memfokuskan pada pembentukan warga negara yang memahami dan mampu melaksanakan hak-hak dan kewajibannya untuk menjadi warga negara Indonesia yang cerdas, terampil, berkarakter yang diamanatkan oleh Pancasila dan UUD NRI 1945 (Depdiknas, 2006). Somantri (2001) menyatakan bahwa, PKn merupakan usaha untuk membekali peserta didik dengan pengetahuan dan kemampuan dasar yang berkenan dengan hubungan antar warga negara dengan negara serta pendidikan pendahuluan bela negara menjadi warga negara agar dapat diandalkan oleh bangsa dan Negara. PKn merupakan mata pelajaran yang membahas tentang pengembangan kemampuan peserta didik agar dapat tumbuh menjadi warga negara yang baik (Samsidar, 2019).

Salah satu kajian yang tercantum dalam dalam pembelajaran Pendidikan Kewarganegaraan (PKn) yang terdapat, dapat diwujudkan dengan penelahaan konsep PKn yang benar, baik dalam bentuk sikap dan konsep-konsep yang benar dapat berimplikasi pada pembelajaran. Karena mata pelajaran PKn masih sangat luas dan memerlukan banyak pengembangan konsep, sehingga untuk mencapai hasil belajar yang baik dan efektif maka sudah tidak diragukan lagi insan pendidik harus memahami dan menerapkan model-model pembelajaran yang benar dan sesuai dengan materi yang dipelajari (Tuken, 2016). Tujuan pembelajaran PKn adalah untuk memberikan kemampuan terhadap warga Negara agar dapat; berpikir kritis rasional dan kreatif dalam menanggapi isu kewarganegaraan, Berpartisipasi secara cerdas dan tanggung jawab, serta bertindak secara sadar dalam kegiatan bermasyarakat, berbangsa dan bernegara (Kurniawan, 2017). Pembelajaran PKn dapat dikatakan berhasil apabila siswa dapat menyelesaikan tugas atau penilaian yang dilakukan oleh guru. Alat penilaian yang digunakan oleh guru harus dapat menjaring kemampuan kognitif, afektif, dan psikomotor sesuai dengan taksonomi Bloom. Dengan demikian penilaian yang dilakukan guru tidak hanya berupa penilaian tertulis namun juga dapat dilihat dari sikap siswa setelah memperoleh materi (Mahmud, 2017).

Dalam proses belajar mengajar guru secara terus menerus memperhatikan kepentingan siswa, pendapat siswa dan memusatkan perhatian pada apa yang dapat siswa tampilkan secara aktual, siswa diberikan tanggung jawab dan kepercayaan menemukan dan mengaitkan pengalaman-pengalaman melalui tugas-tugas yang diberikan (Scuncke dalam Riswan Jaenudin, 1999). Ini berarti guru memberikan fasilitas yang cukup kepada siswa untuk mencapai hasil yang optimal. Dari hasil pengamatan penulis dalam kegiatan belajar mengajar yang telah dilaksanakan di Kelas III SD Negeri Karayunan II Kec.Cigasong Kab. Majalengka diperoleh gambaran bahwa guru dalam memberikan materi pelajaran merasa kesulitan dalam memilih pendekatan pembelajaran yang dilaksanakan di dalam kelas, yang terkadang masih mengarah pada 'guru sentris' seperti pendekalatan klasikal dengan berceramah sehingga siswa merasa kurang bergairah, suasana kelas terasa tegang, tidak rileks dan kurang bermakna yang akhirnya siswa kurang termotivasi dalam belajar yang mengakibatkan siswa berbicara sendiri, kurang memperhatikan, dan akibatnya ketercapaian siswa masih banyak yang belum tuntas.

Permasalahan di atas bisa diatasi melalui kemauan keras guru PKn untuk memperbaiki desain dan strategi pembelajaran di Kelas III SD Negeri Karayunan II Kec.Cigasong Kab. Majalengka dengan mengkaji strategi pembelajaran apa yang sangat tepat diterapkan, sehingga mampu memperbaiki kondisi tersebut. Oleh karena itu, perlu penelitian tindakan kelas yang 
dilakukan oleh penulis bersama guru-guru SD Negeri Karayunan II Kec.Cigasong Kab. Majalengka

Berdasarkan hasil analisis penulis, diketahui bahwa akar penyebab masalah di atas bermuara pada strategi pembelajaran yang masih berorientasi target penguasaan materi,bukan membekali siswa kemampuan untuk dapat memecahkan masalah dalam kehidupan sehari-hari. Strategi pembelajaran kurang mampu membangkitkan ketrampilan berfikir kritis siswa, kurang mengembangkan kemampuan analisis, sintesis dan evaluasi. Kondisi ini terjadi karena strategi pembelajaran masih berfokus pada guru sebagai sumber utama pengetahuan, dan ceramah menjadi pilihan utama strategi pembelajaran.

Dengan demikian untuk mampu mengembangkan kemampuan berpikir kritis siswa, strategi pembelajaran tertentu perlu dilakukan salah satu cara yakni dengan NHT (Numbered Heads Together) . Pemilihan model pembelajaran NHT di atas didasarkan pada keunggulannya. Kaagan (2009:116-117) menyampaikan bahwamodel pembelajaran NHT memiliki keuntungan yaitu siswa akan diajarkan mengenai Social skill, knowledge building, procedure learning, processing info, thinkhing skill, team building, communication skill, decision making dan presenting info, sehingga siswa akan lebih aktif dan mandiri dalam kegiatan pembelajaran sehingga hasil belajarnya juga akan meningkat (Harmini, 2017).

Kelebihan NHT menurut Hill (dalam Setyanto, 2011:44) yaitu: (1) dapat meningkatkan prestasi siswa dalam belajar, (2) mampu memperdalam pemahaman siswa, (3) membantu siswa dalam bekerjasama (kekompakan) dalam kelompok, (4) membantu siswa untuk meningkatkan rasa percaya diri siswa untuk berani berbicara di depan kelas (menjawab pertanyaan), (5) mengembangkan rasa ingin tahu sehingga dapat memunculkan semangat dalam diri siswa untuk dapat memahami materi dan mengetahui jawaban dari soal yang diberikan pada guru, (6) membuat suasana kelas yang menyenangkan saat belajar.Selain itu menurut Sumarmi (2012:52) pada kegiatan pembelajaran ini siswa belajar untuk saling menghormati, menghargai, dan saling berinteraksi dengan temannya yang memiliki latar belakang dan kemampuan yang berbeda. Siswa juga memiliki kesempatan yang sama dalam menyampaikan pendapat kelompoknya.

Hakekat NHT (Numbered Heads Together) ini adalah merupakan perubahan langkah yang sesungguhnya. Metode ini memungkinkan para siswa yang memiliki pengalaman berbeda dalam mempelajari materi yang sama untuk saling membandingkan. Aspek-aspek tersebut adalah aspek-aspek pokok pada pembelajaran PKn sebagai proses. Sehingga dengan model pembelajaran tersebut siswa dapat mengamati sendiri, merasakan, memegang suatu obyek, bekerja menggunakan alat dan bahan, yang pada akhirnya akan memudahkan siswa untuk mengingat materi pelajaran yang telah dipelajarinya. Selain itu dalam model pembelajaran kooperatif tipe NHT ini siswa tidak hanya diberikan tanggung jawab untuk kelompoknya melainkan harus bertanggung jawab pula terhadap dirinya sendiri (Mulyana, 2016).

Model kooperatif tipe NHT ini tepat diterapkan untuk mengatasi permasalahan pembelajaran yang sebagaimana telah diuraikan, karena dengan pembelajaran kooperatif tipe NHT ini akan membuat siswa tidak jenuh dalam kegiatan pembelajaran dan siswa dapat sharing dengan temantemannya untuk memecahkan permasalahan yang diberikan oleh guru, karena guru hanya sebagai fasilitator untuk mengembangkan pengetahuan siswa, serta mampu membuat siswa 
mampu bertanggung jawab lebih baik lagi yang pada akhirnya akan meningkatkan hasil belajar siswa menjadi lebih baik.

\section{Metode Penelitian}

Penelitian ini merupakan Penelitian Tindakan Kelas yang dilakukan secara kolaborasi. Penelitian Tindakan Kelas berdasarkan pendapat Sanjaya (2011: 26) adalah proses pengkajian masalah pembelajaran di dalam kelas melalui refleksi diri dalam upaya untuk memecahkan masalah tersebut dengan cara melakukan tindakan yang terencana dalam situasi nyata serta menganalisis setiap pengaruh dari perlakuan tersebut. Pendapat tersebut sesuai pendapat yang disampaikan oleh Kasbolah (2001: 15), bahwa Penelitian Tindakan Kelas merupakan penelitian tindakan dalam bidang pendidikan yang dilaksananakan dalam kawasan kelas dengan tujuan untuk memperbaiki dan atau meningkatkan kualitas pembelajaran.

Banyak model Penelitian Tindakan Sekolah yang dapat diterapkan, tetapi dalam penelitian ini menggunakan model Kemmis dan McTaggart di mana dalam perencanaannya menggunakan siklus sistem spiral yang di dalamnya terdiri dari empat komponen, yaitu rencana, tindakan dan observasi serta refleksi (Sujati, 2000: 23).

Dari gambar 1 mengenai desain penelitian maka penelitian tindakan yang akan dilakukan dapat diuraikan sebagai berikut:

1. Perencanaan (Plan)

Melakukan observasi terhadap situasi atau kemampuan motorik halus anak sebelum dilakukan tindakan, membuat Rencana Kegiatan Harian terlebih dahulu dengan berdiskusi bersama guru kelas (kolaborator), membuat media yang digunakan untuk kegiatan pembelajaran serta mempersiapkan peralatan yang dibutuhkan bersama kolaborator, mempersiapkan lembar observasi yang digunakan untuk mengambil data serta melakukan penilaian dan evaluasi, melakukan setting atau penataan ruang kelas yang mendukung kegiatan pembelajaran.

2. Pelaksanaan (Act) dan Observasi (Observe)

Pelaksanaan dilakukan sesuai dengan perencanaan yang telah dibuat guru kelas dengan peneliti. Pelaksanaan penelitan dilakukan secara fleksibel yaitu bisa berubah sesuai dengan situasi dan kondisi yang ada di lapangan. Guru kelas sebagai kolaborator melaksanakan tindakan yang sudah direncanakan sesuai RKH sedangkan peneliti mengamati proses pembelajaran yang berlangsung.

3. Refleksi (Reflect)

Refleksi dilakukan pada setiap akhir siklus untuk mengetahui apakah kegiatan mewarnai yang diberikan sudah sesuai harapan atau belum serta digunakan peneliti dan kolaborator dalam melakukan evaluasi tentang perlu tidaknya melakukan siklus selanjutnya. Selain itu, melalui refleksi dapat melakukan analisis data pada lembar observasi yang telah diisi oleh peneliti dan kolaborator serta melakukan penilaian untuk menyusun rencana perbaikan yang akan dilakukan (Arikunto, 2010). 


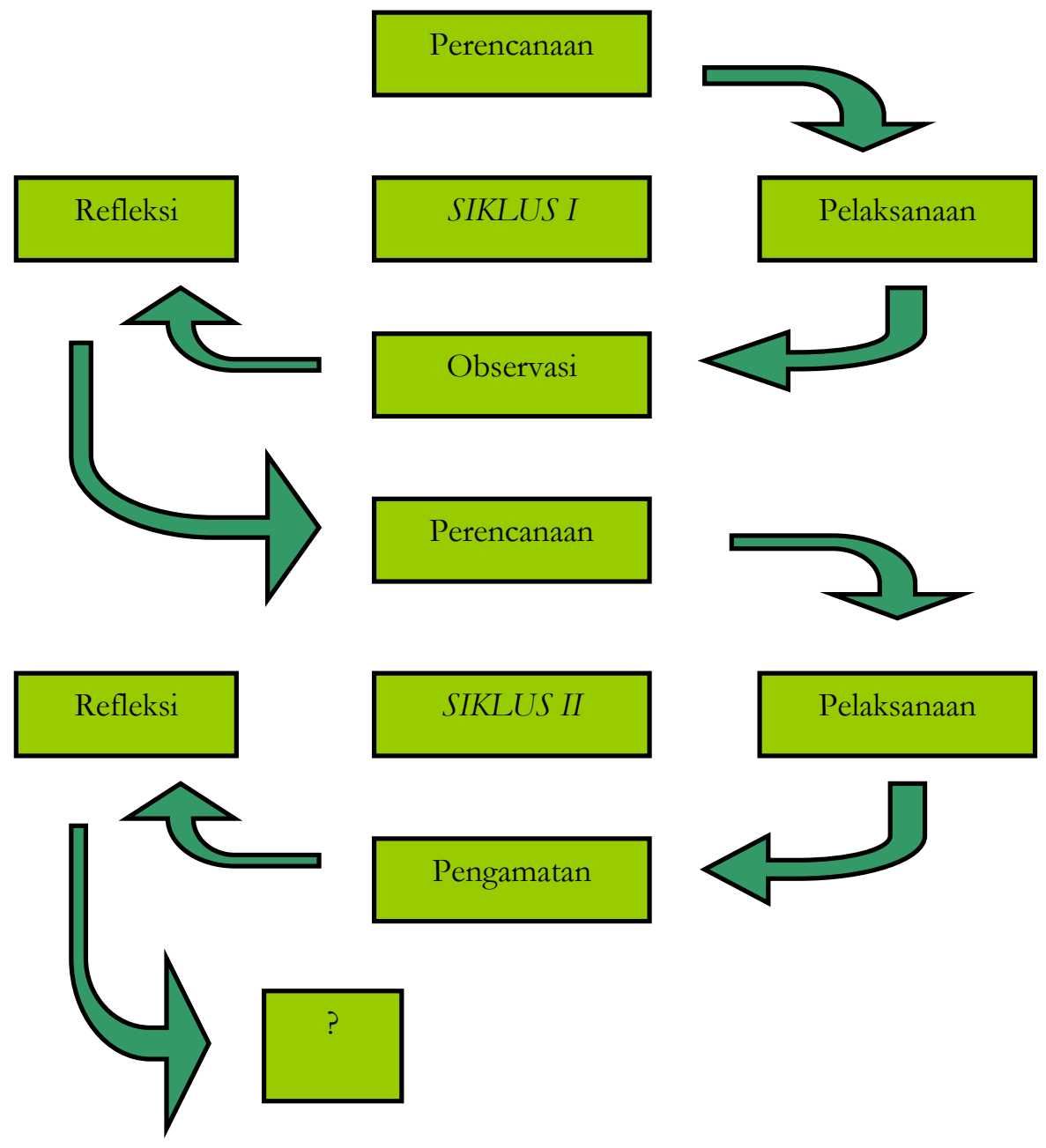

Gambar 1. Model kemmis dan Mc Taggart

Subjek penelitian tindakan kelas ini adalah siswa Kelas III SD Negeri Karayunan II Kec.Cigasong Kab. Majalengka tahun ajaran 2019-2020 berjumlah 20 siswa, Subyek penelitian ini diambil secara keseluruhan, sebagai obyek penelitian karena asumsikan karakteristik dan kemampuan dianggap sama. Dan peneliti ingin mencari strategi pembelajaran yang efektif untuk meningkatkan pemahaman dan hasil belajar siswa.

Instrument yang digunakan untuk mengumpulkan data pad penelitian ini adalah soal uraian dan lembar observasi. Data yang dianalisis dalam penelitian tindakan kelas ini adalah data kuatitatif dan kualitatif. Data kualitatif digunakan untuk memberikan deskripsi tentang pandangan dan pendapat dari subyek penelitian. Data kuantitatif digunakan dengan cara mencatat peristiwa hasil prestasi belajar siswa sebelum adanya penelitian, kemudian diadakannya penelitian tindakan kelas pada siklus pertama dan kedua. Dengan pengelompokan data, maka akan ditemukan nilai terendah dan nilai tertinggi serta ditemukan nilai rata-rata dari sebelum adanya penelitian tindakan kelas, ketika diadakan dan ada perbaikan.

Indikator keberhasilan Penelitian tindakan kelas ini adalah jika terjadi perubahan peningkatan pemahaman siswa pada mata pelajaran PKn melalui NHT (Numbered Heads 
Together). Secara kuantitatif dapat diindikasikan jika $70 \%$. Dari seluruh siswa terlibat pemahaman terhadap mata pelajaran PKn berubah lebih baik. Hal ini diwujudkan dengan adanya kemampuan siswa $70 \%$ dalam menjawab soal pilihan ganda dengan benar. Disamping itu juga $75 \%$ siswa terlibat aktif dalam pembelajaran dengan menerapkan NHT (Numbered Heads Together) . Kemampuan guru untuk mengimplementasikan penerapan Model Pembelajaran tersebut dapat terlaksana dengan baik.

\section{Hasil dan Pembahasan}

Dari hasil evaluasi belajar pada materi "Hak dan Kewajiban Warga Negara"siswa Kelas III SD Negeri Karayunan II Kec.Cigasong Kab. Majalengka, dengan menerapkan NHT (Numbered Heads Together) selama siklus I dan II dapat dilihat melalui tabel berikut:

Tabel 1 Nilai Evaluasi Siklus Awal, Siklus I dan Siklus II

\begin{tabular}{|c|c|c|c|c|c|}
\hline \multirow{2}{*}{$\begin{array}{c}\text { Nomor } \\
\text { Urut }\end{array}$} & \multirow{2}{*}{ Nama Murid } & \multirow{2}{*}{$\mathrm{L} / \mathrm{P}$} & \multicolumn{3}{|c|}{ NILAI } \\
\hline & & & Pra Test & Siklus I & Siklus II \\
\hline 1 & Adli Muhaemin & $\mathrm{L}$ & 50 & 70 & 80 \\
\hline 2 & Anjar Sahditia & $\mathrm{L}$ & 50 & 70 & 80 \\
\hline 3 & Arya Lingga Pratama & $\mathrm{L}$ & 50 & 70 & 80 \\
\hline 4 & Desviga Putri Meyla & $\mathrm{P}$ & 60 & 70 & 80 \\
\hline 5 & Fauzi Firdaus & $\mathrm{L}$ & 40 & 60 & 80 \\
\hline 6 & Imam ihsan Al Mubaroq & $\mathrm{L}$ & 45 & 50 & 80 \\
\hline 7 & Ina Nadratul Hasnah & $\mathrm{P}$ & 40 & 60 & 80 \\
\hline 8 & Isye Nyai Robiah & $\mathrm{P}$ & 60 & 70 & 80 \\
\hline 9 & Khaylilalila Zian & $\mathrm{P}$ & 60 & 70 & 80 \\
\hline 10 & Lusi Natalia & $\mathrm{P}$ & 50 & 60 & 80 \\
\hline 11 & Luthfie Fatih Al Farizi & $\mathrm{L}$ & 70 & 70 & 80 \\
\hline 12 & Muhamad Akbar Fadilah & $\mathrm{L}$ & 50 & 60 & 80 \\
\hline 13 & Nazwa Dwi Natasya & $\mathrm{P}$ & 70 & 80 & 80 \\
\hline 14 & Neng Sheva Aprilya & $\mathrm{P}$ & 40 & 70 & 80 \\
\hline 15 & Nur Anggraeni & $\mathrm{P}$ & 40 & 70 & 80 \\
\hline 16 & Riki Muhamad Mauladi & $\mathrm{L}$ & 60 & 80 & 80 \\
\hline 17 & Seril Rusliansah & $\mathrm{L}$ & 60 & 60 & 80 \\
\hline 18 & Siska Amelia & $\mathrm{P}$ & 40 & 70 & 80 \\
\hline 19 & Tiara Maharani & $\mathrm{P}$ & 60 & 80 & 90 \\
\hline 20 & Titin Hatini & $\mathrm{P}$ & 50 & 70 & 80 \\
\hline & Jumlah & & 1045 & 1360 & 1610 \\
\hline & Rata-rata & & 52,25 & 68 & 80,5 \\
\hline
\end{tabular}

Tingkat pencapaian penguasaan materi pembelajraan "Kerjasama dalam keragaman di sekolah" mengalami peningkatan dari hasil belajar siswa pada awal sebelum adanya tindakan kelas mencapai 52,25, pada siklus I naik mencapai rata-rata 68, dan pada siklus II meningkat mencapai rata-rata 80,5 . 
Tabel 2 Nilai Evaluasi Perkelompok Siklus I dan II

\begin{tabular}{ccccc}
\hline \multirow{2}{*}{ No } & \multirow{2}{*}{ Nama Kelompok } & \multicolumn{2}{c}{ Nilai Evaluasi } & \\
& & Siklus I & Siklus II & Keterangan \\
\hline 1 & I & 60 & 80 & Naik \\
2 & II & 70 & 90 & Naik \\
3 & III & 60 & 80 & Naik \\
4 & IV & 70 & 80 & Naik \\
5 & V & 70 & 90 & Naik \\
6 & VI & 75 & 85 & Naik \\
& Jumlah & 405 & 505 & \\
& Rata-rata & 67,5 & 84,17 & \\
\hline
\end{tabular}

Hasil evaluasi dari kerja kelompok dalam pembahasan materi "Kerjasama dalam keragaman di sekolah" pada siklus I memperoleh rata-rata 67,5 dan pada siklus II naik menjadi 84,17.

Dari data hasil pembahasan secara kuantitatif terhadap hasil pretest dan post test siswa dalam belajar PKn pada materi "Kerjasama dalam keragaman di sekolah" yaitu:

1. Hasil awal (Pra test) menunjukkan skor rata-rata:52,25.

2. Hasil pada siklus I naik menjadi skor rata-rata: 68.

3. Hasil pada siklus II naik menjadi skor rata-rata: 80,5.

Dengan demikian, meningkatnya nilai dari hasil evaluasi belajar PKn pada materi "Kerjasama dalam keragaman di sekolah" pada tiap siklusnya, berarti pemahaman siswa Kelas III SD Negeri Karayunan II Kec.Cigasong Kab. Majalengka terhadap materi tersebut menunjukkan adanya peningkatan yang cukup signifikan. Hal ini dapat dilihat melalui diagram grafik.

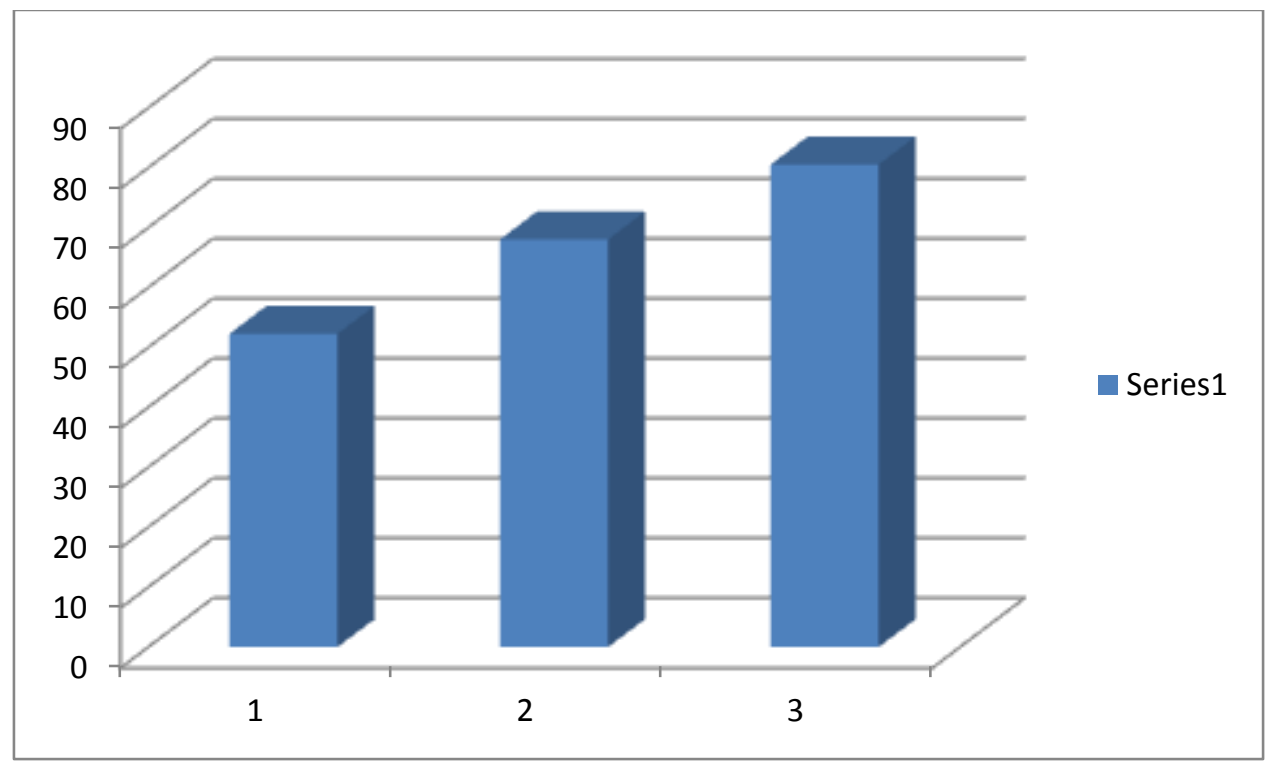

Gambar 1 Diagram Grafik

Peningkatan Pemahaman materi "Perkembangan Konstitusi Indonesia" 
Secara kualitatif dalam penelitian tindakan kelas yang telah dilakukan pada siklus I dan siklus II, maka diperoleh suatu penemuan sebagai berikut:

a. Aktivitas siswa dalam mengikuti kegiatan pembelajaran PKn pada materi "Kerjasama dalam keragaman di sekolah"", seperti:

1) Siswa yang bisa menjawab pertanyaan atau permasalahan meningkat.

2) Siswa yang menyampaikan pendapat meningkat.

3) Siswa yang memperhatikan secara aktif meningkat.

4) Siswa yang mengajukan pertanyaan atau mengungkapkan permasalahan cukup meningkat.

5) Siwa yang bekerja dan belajar secara aktif. Pada siklus I mencapai rata-rata : $70.5 \%$ (cukup baik). Pada silus II mencapai rata-rata : 82.75\% (baik)

b. Kinerja guru dalam kegiatan pembelajaran PKn pada materi "Kerjasama dalam Keragaman di sekolah ", menunjukkan pada siklus I menunjukkan rata-rata $68 \%$ (cukup baik). siklus II naik, dan menunjukkan rata -rata 80,5\% (baik sekali).

Berdasarkan penjelasan di atas dapat disimpulkan bahwa hipotesis tindakan terbukti, yaitu dengan menerapkan NHT (Numbered Heads Together) dapat Meningkatkan Pemahaman siswa dalam belajar PKn pada materi "Kerjasama dalam keragaman di sekolah" di Kelas III SD Negeri Karayunan II Kec.Cigasong Kab. Majalengka.

\section{Kesimpulan}

Berdasarkan hasil penelitian dan pembahasan, maka disimpulkan bahwa model Numbered Heads Together dapat meningkatkan hasil belajar siswa pada materi "Kerjasama dalam keragaman di sekolah" di Kelas III SD Negeri Karayunan II Kec.Cigasong Kab. Majalengka. Peningkatan tersebut dapat dilihat dari adanya peningkatan persentase dari sebelum tindakan dan setelah pelaksanaan tindakan pada siklus I dan siklus II. Keberhasilan tersebut tidak terlepas dari langkahlangkah pembelajaran Numbered Heads Together yang memfasilitasi kesempatan kepada siswa untuk belajar secara mandiri.

\section{Daftar Pustaka}

Arikunto, dkk. (2010). Penelitian Tindakan Kelas, PT. Bumi Aksara, Jakarta.

Dahlan, M.D, (1990). Psikologi Pendidikan. Pustaka setia. Jakarta.

Depdiknas. (2006). Kurikulum Tingkeat Satuan Pendidikan. Jakarta : Depdiknas.

Harmini. (2017). Penerapan Model Pembelajaran Numbered Heads Together Untuk Meningkatkan Aktivitas Belajar Dan Hasil Belajar Ips Siswa Kelas VIII G SMPN 2 Ponorogo. Gulawentah: Jurnal Studi Sosial. Volume 2 Nomor 1. hal 13-21.

Kagan, S. (2009). Cooperative Learning. San Clemente:Kagan Publising

Kasbolah, Kasihani. (1999). Penelitian Tindakan Kelas (PTK). Malang: Depdikbud.

Kurniawan, M. (2017). Meningkatkan Hasil Belajar Pendidikan Kewarganegaraan Melalui Strategi Active Learning. Pedagogia : Jumal Pendidikan. Volume. 6, No. 1, Februari 2017 hal. 124-132 
Mahmud, A.R.H., Saneba, B., \& Jamaludin. (2017). Meningkatkan Hasil Belajar Siswa Pada Pembelajaran PKn Melalui Pendekatan Pembelajaran Kooperatif Tipe STAD Kelas IV SD Inpres Koyoan. Jurnal Kreatif Tadulako Online. Vol. 5 No. 1.hal 44-52.

Mulyana, Hanifah, Jayadinata. (2016). Penerapan Model Kooperatif Tipe Numbered Heads Together (NHT) Untuk Meningkatkan Hasil Belajar Siswa Pada Materi Kenampakan Alam Dan Sosial Budaya. Jurnal Pena Ilmiah: Vol. 1, No. 1. 331-340.

Samsidar. (2019). Upaya Meningkatkan Hasil Belajar Pkn Melalui Model Pembelajaran Scramble Siswa di SDN 13 Muara Kuang. Jurnal Ilmiah Bina Edukasi. Vol. 12, No. 1, 16-30.

Sanjaya. (2011). Penelitian Tindakan Sekolah. Jakarta: Kencana.

Sadulloh, Uyi, dkk. (2007). Pedagogik. Bandung: Cipta Utama.

Somantri. (2001). Menggagas Pembaharuan Pendidikan IPS. Bandung: Remaja Rosda Karya.

Sumarmi. (2012). Model-Model Pembelajaran Geografi. Malang:Aditya Media Publising.

Sujati. (2000). Penelitian Tindaka Kelas. Yogyakarta. FIP. UNY.

Tuken, R. (2016). Peningkatan Hasil Belajar Siswa Pada Mata Pelajaran Pkn Melalui Pembelajaran Kooperatif Tipe Role Playing Di Kelas VI SDN IV Kota Parepare. Volume VI Nomor 2 Juni 2016. Hal 123-129 